\title{
Teaching of the NOS in Physics and Chemistry Education: Odds and Evens
}

\author{
Ahmet Tumbul ${ }^{\mathrm{a}}$ \\ Mustafa Durgun ${ }^{b}$ \\ Zekai Ayık \\ ${ }^{a}$ Harran Üniversitesi, Rektörlük, Şanlıurfa,Türkiye \\ ${ }^{b}$ Harran Üniversitesi, Fen-Edebiyat Fakültesi, Kimya Bölümü, Şanlıurfa,Türkiye \\ ${ }^{c}$ Harran Üniversitesi, Eğitim Fakültesi, Matematik ve Fen Bilimleri Eğitimi Bölümü, Şanlıurfa,Türkiye
}

\begin{abstract}
In science education many researches and studies have demonstrated importance of nature of science (NOS) and they claimed that teaching of NOS is the ultimate goal of science education. Given importance has been emphasized to reflect on all components of science education from school environment to curriculum content. Besides, many researches embraces a view that beliefs of science teachers about NOS and epistemology of science have a direct effect on their instructional practices. Although numerous global and local (Turkey) attempts aim to teach a satisfactory level of understanding about NOS and pave epistemological beliefs in line with the modern philosophical approaches for both students and teachers, most of the researches, authentic or novel, have demonstrated unsatisfactory results. This study has two main goals. First aim is to reveal sophomore pre-service science teachers' epistemological beliefs and views about the NOS. Secondly, evaluate the results in the lights of previous constructivist efforts that aims to transmit NOS views in line with consensus view. To reveal the views about the NOS, VOSTS test was used. 45 sophomore pre-service science teachers responded the test and the results were quantitatively analyzed. The results showed that eight of ten items were mostly responded in a positivist approach. Because the results of the questionnaire demonstrated that most of the participants have positivist views, it was questioned that why still the level of understanding of the NOS is not satisfactory. Additionally, results showed that participants, who had been educated by constructivist science curricula that has mainly supported consensus view of NOS teaching, showed weak level of understanding NOS. In a similar vein, possible reasons were proposed and discussed in the light of previous studies for inadequate level of understanding of the NOS. Results imply that teaching of the NOS seems far from being contextualized with daily life and science as a human enterprise.
\end{abstract}

Atıf bilgisi: Tumbul, A., Durgun, M. \& Ayık. Z. (2019). Teaching of the NOS in physics and chemistry: odds and evenss, Harran Maarif Dergisi, 4 (1), 65-85. doi: 110.22596/2019.0401.65.85

Sorumlu yazar: Zekai Ayık, e-posta: zekaiayik@harran.edu.tr

\section{ARTICLE TYPE}

Research

\section{ARTICLE HISTORY}

Received 3 April 2019

Accepted 27 May 2019

\section{KEY WORDS} Nature of Science, Science Education.
Epistemological Views, 


\section{Introduction}

The aim of science education has been a controversial issua in the field of science education for almost sixty years. Put differently, firstly what science teaching should focus on is controlversial. Secondly, what kind of abilities and capabilities students should obtain at the end of the process have been criticized by science education community. Abd-El-Khalick(2001), proposed that science teaching is to assist students have an adequate understanding and conception about the NOS. Idea to understand the nature of science and to obtain scientific inquiry skills parallel to educational level is mostly accepted mission of science teaching. Allchin (2014) proposes that aim of science education in a contemporary society is to educate student who have functional scientific literacy skills. Accordingly, a students should know how science works and how scientific knowledge is produced in order to interpret scientific claims in socio-scientific issues and in a social life that is surrounded by science and its products (Allchin, 2017). Being as a component of scientific literacy or as a direct aim of science education, understanding characteristics of NOS seems an indispensable element of science education (Abd-El-Khalick \& Lederman, 2000a; McComas, Clough, \& Almazroa, 1998; Millar \& Osborne, 1998; Lederman, 2007).

In the past, especially after 1950's, curricular attempts such as Harvard Project Physics or curriculum project of Klopfer and Cooley (1963) namely "History of Science Cases for High Schools" (HOSC) aimed to promote understandings of the NOS. The function of science education has been considered as teaching practices of science and knowing characteristic aspects of science methods. After World War II, especially in the USA, there seemed enormous efforts for prompting science education to grow a new generation who have positive attitudes toward science and who wish to do science as a profession. In this wise, theoretical attempts to characterize production of scientific knowledge, science methodology and teaching of the first two were paved. Especially, after the launch of Sputnik and especially in the USA, there abruptly seemed plenty of researches in the field of science education in both K-12 and undergraduate level (Matthews, 1998). Many researches (Abd-ElKhalick, 2001; Barufaldi, Bethel, and Lamb, 1977; Carey and Stauss, 1970; Mackay, 1971; Lederman, 1992; Scharmann, 1990) investigated to reveal views of K-12 students, pre-service science teachers, non- science majors, and in- 
service teachers' about science. Many studies aiming to enhance conceptions and understandings about NOS have been conducted relatedly.

Parallel to those attempts, several survey and testing instruments were developed to reveal views and conceptions about NOS. Some of them were TOUS of Klopfer \& Cooley (1961), VOSTS of Aikenhead and Ryan (1992), VNOS test of Lederman et al, (2002). Moreover, teaching the NOS has been one of the most focused reserach area in science education. In relevant literature, it can be understood that instructional strategies to teach NOS were depend on the conceptual characterizations of NOS. For example, consensus view of the NOS (Lederman, 1992; Osborne et al., 2003; Smith \& Scharmann, 1999) is a proponent to teach NOS in a narrative and declarative teaching strategy. Put differently, they aim to teach declarative knowledge that is obtained through congnitive processes. Latour (1987) calles such an understanding of science as "ready-made science" and Kolsto (2001) calls it as "textbook science". Those supporters generally argue that understanding of NOS simply involves knowing a list of characteristics that delineate scientific methodology and scientific knowledge (Smith \& Scharmann, 1999).Many science scholars (Allchin, 2014; Hodson; 2008; Irz1k \& Nola; 2011) claim that consensus view of NOS is narrow and it has disadvantages. The most cited disadvantages are proposing of declarative knowledge, and omit of scientific inquiry. Another approach in teaching of NOS proposes that understanding how science works and how scientific knowledge is produced can be achieved by student only if they do science inquiry activities. Again Latour (1987) calls such an approach as "science-in-the-making" and Kolsto (2001) calles as "science frontier". Osborne (1997, p.11) explicates that, science-,in-the making can be answer for "how we know" and it is too difficult for the account of consensus view.

Integrated View of Niaz (2016) deems that appropriate NOS views can be achieved by both learning declarative knowledge and doing science. It firstly suggest a narrative teaching of the NOS, and then doing science in an authentic and retrospective ways. Family Resemblance View (FRA) (Irzik \& Nola, 2011) assumes that the definition of the NOS should include scientific inquiry and disciplinary science activities. Accordingly, they proposed there is a polythetic set of characteristics according to which disciplines of science can be classified as similar or dissimilar. Besides, a developed version of FRA view of NOS emerged as "Re-conceptualized FRA-to-NOS, (RFN) view (Kaya and Erduran, 2016).

Definition and contextualization of NOS are still controversial issues. Although Kolsto (2001) sees the tension between "textbook science" and 
"science frontier" as a factor that creates an argumentation among science educators, he notes that proponents of consensus view see "consensus view as non-controversial" because it was determined by science education community after "criticism, argumentation, and peer review processes" Although discussing essential issues and problems posed by science educators about NOS is too broad for the scope of this study, it cannot be actually, Allchin's (2017) reasonable claims that monitor conceivable causes of those controversies can be emphasized. According to him before addressing the answer of the question "What is NOS" we should focus on the question of "Why NOS?". He adds that educators of science community accepted the necessity of NOS teaching "without enough justification". He put forth the answer of "why NOS" as understanding NOS for functional scientific literacy in which students should understand how science works in order to interpret the reliability of scientific claims especially in socio-scientific issues. Such an understanding of NOS begins from laboratory benchs and continues to newspapers, in other words, students should know how scientific knowledge produced, conceptualized, and socialized. In such an awareness, students should expertise biases, cultural, effects, errors or conflicts of interests in each steps as citizens and consumers in modern society. In such a pragmatic and functional approach, Allchin (2014) proposed ways of knowing "how of NOS" can be conceptualized and it does not logically dismiss cognitive and practical aspects of NOS teaching. He proposes three ways of conceptualizations as student led inquiry activities, contemporary cases, and historical cases.

In a different point of view, the philosophical approaches of scholars seem having critical influences for characterizations of NOS. In philosophy of science; positivism (Comteanism), and Popperianism (naive falsificationism), conventionalism (Kuhnianism), and Lakatos's methodology of scientific research programs can be thought as four main normative methodologies in philosophy of science. If we want to understand a body of systematic accumulation of beliefs and knowledge and if we want to characterize it, we need to look its roots and past. In other words, it is the historical reconstruction (Lakatos, 1971) that can help to characterize it. According to Lakatos (1971), in which philosophical eye we look to history, we reconstruct the NOS according to that philosophical approach. It is a lens through which we look past and characterize the process and its products. Lakatos (1971) put forth that the philosophical approach is the most important factor to characterize science so the NOS. Although many science educators (e.g. Allchin, 2017) think that teaching NOS as embedded in philosophy is too academic, it proposes an epistemological underpinning and credibility of scientific knowledge. 
Revealing particular group of people's views about the NOS situates a cornerstone. Because it involves following elements; figuring out conceptions of NOS, understandings about the NOS, and demonstrating epistemological beliefs. Accordingly, revealing NOS views of that group delineate the success of previous efforts which aimed to promote teaching of the NOS and epistemological beliefs. As Deng et al. (2011) report, most of revealing instrumets are surveys, questionnaires and interviews. Interestingly, most of the studies that were conducted to reveal NOS views of students, pre-service science teachers, and science teachers showed inadequate level of understanding and conception about the NOS. Regarding that fact, Lederman (2007) reports that attempts aiming to promote better understandings of the NOS are not satisfactory.

Deng et al. (2011) reviewed 105 empirical studies which aimed to investigate students' views of NOS. Main goal of the study was to investigate philosophical foundation of studies which were categorized into three theoretical framework. First framework was unidimension according to which studets views were labeled as in a "continuum" ranging from empiricist view to constructive view. Second categorization was multi-dimension theroretical framework that poses views about NOS can be divided into subdimensions and toward those dimension students may have different philosophical view. Last and third theoretical framework was argumentative resources framework that does not focus on views of NOS as products of a cognitive process, declarative knowledge (Allchin,2017) or proper, beliefs (Matthew, 1998). It focuses on the linguistic structure and process during construction of scientific arguments. Argumentative resources involves discourse potentials students demonstrate in a science activity.

Study of Deng et al. (2011) argues strengths and limitations of those categorical properties. It was explicated that the first two theoretical framework categories are founded on constructivist philosophy and 96 of 105 researches were among them. This situation tells us that researches on NOS were dominantly found on constructivist philosophy and their perception of NOS knowledge was parallel to ready-made-science (Latour, 1987) or textbook science (Kolsto, 2001). Especially after 1980s, effects of constructivist philosophy emerged on NOS studies including psychological and sociocultural factors (Deng et al., 2011). Context of this study relates dominance of constructivist studies. Therefore, the empirical part of this study embraced constructivist approach to gather participants views about NOS.

According to Lederman (2007), teaching of the NOS is a ramified phenomenon, in other words, it has various dimensions and elements to 
consider altogether, not separately. Students, teachers, school environments, textbooks, curriculum or educational policies are crucial factors for teaching of the NOS. In a classroom, the role of teacher is to transmit knowledge about NOS to students through appropriate instructional methods and strategies. Lederman (2007) also proposes that what kind of views a teacher has then it is mostly transmitted to her/his students. Therefore, educating the future's science teachers considering NOS has a deciding status about future students' conceptions and understanding about the NOS.

Besides, some researches (Duschl \& Wright 1989; Brickhouse, 1989; Tsai, 2002) demonstrated relationships between belief of teachers about the nature of knowledge and knowing and disciplinary learning experiences of their teachers. Maggioni and Parkinson (2008) conducted an extensive study to see 'relations between teachers' knowledge, experience, epistemic cognition, epistemic beliefs, and calibration and their effects on pedagogical practices". They figured out a significant relationship between those constructs. Although their study does not focus solely on epistemological beliefs and philosophical stances, but it implies, and somewhat points out, that epistemological beliefs of a teachers have a significant role in their teaching performance, the instructional discourse and subsequently on learning process and built of knowledge for their students.

In a similar vein, Hashweh (1996) investigated effect of epistemological beliefs of 35 in-service science teachers on their classroom practices. It was found that teachers embracing constructivist beliefs have better implementation of following practices;

(a) "Are more likely to detect student alternative conceptions"

(b) "Have a richer repertoire of teaching strategies";

(c) "Use potentially more effective teaching strategies for inducing student conceptual change"

(d) "Report more frequent use of effective teaching strategies"

(e) "Highly valuate these teaching strategies" (Hashweh,1996)

In such a constructivist approach of NOS view, this study employs multidimension theoretical framework from categories of Deng et al. (2011). It can be put forth that NOS views of science teachers and their epistemological beliefs affect the science teachers' instructional potentials and strategies. Although Hashweh's (1996) characterization does not involve functional 
scientific literacy (or Allchin's contemporary cases in a classroom), it has substantial implication for NOS views of participants, particularly, who have been taught in a constrctivist science education. In this context, revealing NOS views of pre-service science teachers was an interest of this study. Sophomore pre-service science teachers' views about the NOS were surveyed and the status after a year of university education was investigated. The theoretical framework of this study embraces the consensus view regarding characterization of the NOS. Therefore the conceptual framework was built according to the consensus view and the testing instrument was chosen so that it can reveal views parallel to consensus view.

In a local view, in Turkey, there have been many studies to analyze science curriculums regarding the NOS and to reveal NOS views of science students, pre-service science teachers and in-service science teachers. Özden and Cavlazoğlu (2015) analyzed 2005 and 2013 Turkish science curriculum and found that, especially in 2013 science curriculum, teaching of the NOS is directly emphasized. This situation revealed that there were curricular attempts to teach the NOS as a component of scientific literacy. Gürses and Doğan (2005) conducted a study that aimed to reveal views of pre-service science teachers and found participants as lacking insufficient understanding and knowledge about the NOS. Özdemir (2010) conducted a study and found that science teachers were lacking to understand the NOS. After five years, Aslan, Yalçın, and Taşar (2015) found that science teachers had misunderstandings and misconceptions about definition of science, the NOS, scientific knowledge. After 2 years of this study, Mıhladız and Doğan (2017) found that pre-service science teacher were not satisfactory to understand the NOS and they were not capable to teach the NOS.

It can be seen that studies mentioned above had similar aims and had similar findings and implications in distant times, although later curriculum highlighted the importance of learning and teaching of the NOS. Regarding revealing the views of pre-service science teachers about the NOS, it was an aim to see whether any difference with findings of previous and similar studies. However, this study has two particular aims; firstly to figure out philosophical views of participant pre-service science teachers toward NOS and epistemology of science and, secondly, discuss findings in a comparison to previous studies and attempts devoted to teach NOS.

So far, different perspectives and different implications of NOS teaching were discussed and somewhat compared. No matter what kind of study was done, there have been many studies devoted for characterization, contextualization, or survey NOS views. Although 
critizicing all approaches and synthesizing an authentic one are too sophisticated for the scope of this study, it is inevitable to ask that why most NOS researches revealed inadequate understanding level? Especially, in constructivist consensus view. Allchin (2017) remarks that educators of science accepted necessity of NOS education without enough justification, but his phrase was about the controversies in definition and contextualization of NOS. The essential question lies here as "Why students who were educated in explicit NOS teaching strategies and who were taught by "declarative knowledge" of NOS (Allchin, 2014) still fail in questions asking those explicit and cognitive products?" In the light of this interest and question, this study has two aims in its context;

1) To reveal sophomore pre-service science teachers' views of NOS in Deng et al.'s (2011) multidimensional theoretical framework. Main aims was to see the situation after constructivist curricular development in 2004 in Turkey.

2) To assess and evaluate the situation whether constructivist science curriculum was successful on teaching construstivist founded NOS views.

\section{Methodology}

Methodology of current study is built on descriptive design. Conceptual framework of this study was constructed to make an extensive literature review and obtain descriptive data. Descriptive data has a role as empirical support for theoretical considerations. Additionally, a conceptual base was founded on theoretical evaluation, stemming from an extensive literature review about the NOS studies, that firstly aimed to see the whether there was a gap between the level of understanding of the NOS as expected by previous efforts and level quantitative data revealed and secondly, if there is a gap, to propose possible claims why the aimed level was not still succeeded. This study embraces Deng et al. (2011) multi-dimensional theoretical framework for data collection methodology. According to Savin-Baden and Major (2013, p.184) "a framework is a structure that is intented as a guaide for thinking about the research subject and as an interpretative lens through which to view data. In this wise, this study embraces Deng et al. (2011) multi-dimensional theoretical framework for data collection methodology. In other words, after many efforts including curriculum development, teacher education or enhancing instructional facilities in all level of education to promote understanding of the NOS and epistemological beliefs, this study conducted to see the situation and evaluate the results. 


\section{Sampling}

45 sophomore pre-service science teachers voluntarily participated to the study. Sampling method was convenience sampling through whics sample was considered to resemble population of junior pre-service science teachers. Participants had taken general science courses, such as physics, chemistry, mathematics, but no biology course was taken. Participation was up to volunteerism and required permissions were taken from the faculty of education they study. Participants were facilitated with ample time and they were given a test.

\section{Data Collection Instrument}

Lin and Chen (2002) modified a survey which was a combination of VOSTS test (Aikenhead and Ryan, 1992) and a questionnaire developed previously by Solomon et al. (1992). This test was prepared on foudational bases of "Consensus View" of NOS. As it was mentined before, consensus view of NOS approaches cognitive process of NOS teaching and learning and asks for declarative knowledge (Allchin, 2017). However, the test cannot be thought as mere true-false test, it explores views of participants pertaining NOS. In other words, it is not directly survey what Matthews 's (1998) consideration as "tendency to judge success in teaching the NOS by the degree to which students adopt our views on subject", it explores participants' conceptions of NOS elements determined by consensus view and categorizes them into a philosophical categorization.

\section{Data Analysis}

The survey has ten items including cagtegorical multiple-choice answers. Given answers were classified as Logical-empiricist which portray positivist approach of philosophy of science (mostly views of Vienna Circle) and post-positivist approach which delineates modern philosophical view. According to logical-empiricist view knowledge, scientific theories, laws or principle are laid in the nature and scientists discover them. However, post-positivist view generally declares that science is a human activity according to which scientists invent them. From those points of views, the responses were categorized. In multiple choice items, one of choices represents post-positivist the remaining possess logicalempiricist view. Results were quantitatively analyzed and frequencies and percentages of given categorical answers were expressed in quantitative description to decide which philosophical view is dominant among the participants regarding the NOS. 


\section{Findings}

Quantitative data gathered and analyzed. Results of the responses given to the questionnaire were analyzed as in frequencies and percentages in a descriptive manner (See in Table-1).

Table 1. Frequencies of Categorical Answers

\begin{tabular}{lllll} 
& \multicolumn{2}{c}{ Logical Empiricist } & \multicolumn{2}{c}{ Post-Positivist } \\
\hline Item & f & $\%$ & f & $\%$ \\
Item-1 & 29 & 64,4 & 16 & 35,6 \\
\hline Item-2 & 34 & 75,5 & 11 & 24,5 \\
\hline Item-3 & 16 & 35,6 & 29 & 64,4 \\
\hline Item-4 & 29 & 64,4 & 16 & 35,6 \\
\hline Item-5 & 35 & 77,7 & 10 & 23,3 \\
\hline Item-6 & 38 & 84,6 & 7 & 15,4 \\
\hline Item-7 & 32 & 71,1 & 13 & 28,9 \\
\hline Item-8 & 32 & 71,1 & 13 & 28,9 \\
\hline Item-9 & 14 & 31,1 & 31 & 68,9 \\
\hline Item-10 & 29 & 64,4 & 16 & 35,6
\end{tabular}

The first item was related to the nature of theories. It was asked whether theories represent reality or they are created by scientists to explain phenomena in the nature. The results showed that $64,4 \%$ of participants think that they are copy of reality in a Logical Empiricist view and minor remaining thinks in a post-positivist view. In the second item, again it was asked about nature of theories to reveal whether theories are discovered in the nature or created by scientists. The results showed that 75,5 \% of participants were in logical-empiricist view and it is similar to result of first item. In the third item, views about the relationship between a theory and interpretation of experimental data were surveyed. Views on this point were most of post-positivist whose percentage was about $64,4 \%$. Views about tentativeness of science were surveyed in the item-4. $64,4 \%$ of participants declared logical-empiricist view according to 
which science has unchangeable facts and its products (scientific knowledge) resist to be altered. In item-5, it was asked about foundations of scientific laws, theories, and principles. $77.7 \%$ of participants, declared Logicalempiricist view according to which those scientific knowledge exist in nature and scientists discover them whereas remaining expressed that scientists invent them. Item- 6 surveyed views about expectations of scientists before an experiment. In other words, views concerning roles of presuppositions and the theoretical paradigm scientists believe were examined. In this context, it was found that $84.6 \%$ of participants have logical-empiricist view according to which sometimes scientists have expectations before an experiment and mostly they just perform and wait for the results without any prediction. In item-7, it was asked how scientific community accepts a theory if there are two theories that can explain same phenomenon. The simplicity was the key factor. $71,1 \%$ of participants have logical-empiricist view according to which scientific community accepts both of the theories. Item- 8 asked views about the aims of scientists in performing scientific experiments. About $71,1 \%$ of the responses claimed that scientists perform experiments in order to try and have new discoveries in a logical-empiricist view. Remaining declared post-positivist view responses according to which they perform experiments so that they test their hypothesis. Results of item-9 demonstrate that $68,9 \%$ of participants have post-positivist view pertinent to explanation of a scientific theory, and the major remaining have logical-empricist. Item-9 is one of two items toward which mostly post-positivist views declares (the first was the third item). The last item tried to reveal views concerning why scientists in past believed different theories. The item also explored the views, why theories of a certain group were accepted and why another group/s' were not accepted by scientific community and the roles of experiments in such an acceptation. $64,4 \%$ of participants declared logical-empiricist view and remaining was post-positivist.

\section{Discussion and Conclusion}

Many researches have pointed out that how a science teacher knows and thinks about the NOS has a great effect on what their students understand about characteristics of science (Abd-El-Khalick, 2001; Lederman, 1992; Lederman, 2007). Besides, their understandings about NOS and epistemological beliefs reciprocally influence teaching practices. (Hashweh, 1996; Tsai, 2002). In such a wise, this study aimed to see sophomore pre-service science teachers's NOS views and epistemological beliefs in a brief look. Given responses were categorized as logicalempiricist or post-positivist. In other words, the study had a purpose to 
see what kind of view the participants have about the NOS and epistemology of science. Results showed that major part of the participants have logicalempiricist view about the nature of scientific theories and definition of them. What is more, more than sixty percent of participants think that science is not a human product, its laws, theories or principles wait to be discovered in the nature. However, post-positivist view states that scientific activity is a human enterprise. Participants have mostly post-positivist views about role of presuppositions and theories in scientifics observations. This item showed that scientists are not objective mechanism and they have expectations and prediction in accordance with theories they believe. Tentativeness of science is a vital component in the consensus view list. The results showed that participants believe science finds absolute solutions and unchangeable facts. This finding seems to figure out a relationship between views, one of which declares science is not a human product, and second of which expresses science has absolute truths. In other words, participants seem to think science as a system of absolute truths that finds objective and unchangeable solutions to problems. Those findings also imply that there is a lack of epistemological underpinning concerning scientific knowledge.

Sophomore pre-service science teachers, after first year, mostly with science courses such as physics, chemistry, or mathematics, declared dominantly logical-empiricist NOS views. Although Carey and Stauss (1970) express that there exists dependence between understanding of the NOS and the number of science courses taken, this study (especially assumed to reveal views about tentativeness of science and nature of scientific theories) showed vice versa. In the first year participants took general chemistry and physics courses. Those courses have science content presenting many physics and chemistry theories and laws. Those theories and laws are transmitted without enough contextualization and justification. A powerful support to this claim is study of Niaz and Coştu (2009). They analyzed Turkish general chemistry science textbooks, and they found that used science textbooks are weak to depict characteristics of NOS. Effects of textbook presentations on NOS views seem another possible and responsible causes of weak level of NOS understanding (Jenkins, 1996).

It was revealed that sophomore pre-service science teachers have dominantly logical-empiricist views which do not reflect and embrace modern philosophy and epistemology of science. Therefore, it seems that teacher in such a retrospective and obsolete views cannot prepare their students to modern, human centered and technologically innovated eras. Although, there were a lot of efforts to enhance understandings about the NOS in the past, pre-service teachers 
seem to have lack of understanding about the NOS. Although most of the participants have post-positivist view about definition of a scientific theory, most of them seems lacking of understanding about the role of theories in history of science and how theories were accepted by the scientific community in the past. Additionally, in the lights of those findings, participants mostly seem to have a logical-empiricist view about progress of science. This situation poses that, while science curriculum designed in 2013 in Turkey concentrated on methodology of science and scientific literacy, participants were still far to understand progress of science.

Many studies (Niaz, 1998; Seung, Bryan, \& Nam, 2009) have intended to reveal views of pre-service science teachers about the NOS and almost all of them found participants as weak according to assessment criteria they possessed. Furthermore, most of them tried to perform an intervention to promote NOS understandings and conceptions. Those findings in the literature pose similarity with the results of this study. One of the main functions of this study was to point to why pre-service science teachers have been found to be weak in terms of understandings about the NOS and having weak epistemological beliefs.

There seem some lessons to be taken from findings of NOS survey. Although numerous studies, efforts aiming curricular regulations, or instructional reforms have been done, still, almost all of students have positivist beliefs about the NOS. Abd-El-Khalick (2001) proposed that main goal of science education is to teach the NOS and eventually facilitating students to be scientifically literate (Lederman, 2007). Furthermore, it has been aimed to educate students in a modern philosophical and epistemological scientific approach (Justi \& Gilbert, 2000; Niaz, 2001; Niaz \& Rivas, 2016). The question arises here as following; why almost all of studies found the participants, students, pre-service teachers of in-service teachers are lacking aimed objectives of science education? In other words, despite the curricular reformations were done in a constructivist approach and despite the science curriculum addressed expilicitly teach NOS as labelled by Kolsto (2001) as "textbook science" approach why we cannot get the level we want. According to assumptions of this study in the context of consensus view of NOS there could be two explanations;

a) The efforts were insufficient to teach and demonstrate an understandingof the NOS in a constructivist (for most philosophers of science modern) philosophy and epistemology of science. Those efforts should be included explicit or implicit teaching of the NOS. 
b) Having an understanding of the NOS and epistemological beliefs may need an experience of scientific activity, a level of content knowledge gathered through cognitive and experiental processes and an intellectual accumulation.

For the first case, Abd-El-Khalick and Lederman (2000) reported that for decades there studied many strategical ways (including teacher education, curriculum arrangements, instructional methods etc.) to teach the NOS but still various studies from different parts of the world report weak levels. As Lederman (2007) pointed out that teaching of the NOS not a single rooted phenomena, researchers and practitioners in science education community should not deem it as an integration of different parameters. For instance, a teacher educated in a positivist curriculum cannot teach in modern approach or teaching of the NOS cannot be achieved in a classroom environment which is serves classical classroom interactions with its number of students, instructional tools and devices, or textbooks that are prepared in positivist eyes. In other words, Lederman's (2007) proposals imply that teaching of the NOS can be succeeded with its all elements from teacher to textbooks. Niaz and Coştu (2009) analyzed 21 general chemistry textbooks and they found almost all of them prepared in a positivist/inductivist approach. Furthermore, the participants in this study were used a chemistry textbook which was previously found by Niaz and Coştu (2009) as prepared in an inductivist approach. Their findings demonstrated the imbalance within and insufficiencies in efforts to promote teaching of the NOS.

For the second case, Monk and Osborne (1997) and Masson and Vazquez- Abad (2006) claimed that evolution of scientific ideas and scientific attitudes show a similar progress within history of science and education of students. Idea of Monk and Osborne (1997) situates a thought according to which positivist epistemological beliefs can be expected from student studying in a lower level of education and from that lower level to higher level she gradually get closer modern understanding of the NOS and epistemological beliefs. In such an approach, it is expected from an elementary school student to have positivist understanding about the NOS make own characterization of science up to it. However the study had participants of second year university students and future's science teachers. As a result, although the two cases would be possible if the study was conducted with students below high school level. However, the results of this study support imply the validity of the first case.

Here there should be some additional perspectives, that can be seem out of context at first glance, to put forth. Present study was mainly conducted to 
review popular NOS perspectives and specifically consensus view was laid on the table and some criticisms were posed toward it. There could be make an analogy between proponents and opponents of consensus view. The analogy could be roughly a case as a person living a developed city that has social rules and ethics. That person should know the rules-such as traffic rules specifically stopping the car as the traffic light turns to red. In school teacher educates him to know rules of traffic in the city. However, that person decides to stop in front of a that lamb which exists in a place where there is no camera recording or no police officer. If the person stops the knowledge he has employs a meaning but if he does not stop there is no difference between knowing or not knowing the rule. It seems that proponents of consensus view of NOS foucses mostly on knowing the rule and, in contrast, opponents or science educators who think consensus view is narrow focuses on whether he stops or not, not on knowing the rule or not. In such a point of view, consensus view of NOS proposes premature understanding level for NOS and the knowledge it teaches about how science works seems essential. As in phrases of Ryder (2001), Kolsto (2001), and Allchin (2017); more important thing is to contextualize and problematize knowledge about how science works and how scientific knowledge produced within daily life cases and socio-scientific issues. If that awareness does not go beyond classroom, science has no meaning for students as lay people (Durant, 1994), citizens, and consumers of science technology society. Unfortunately, results of this study demonstrate that knowledge of how science work and how scientific knowledge produced could not obtained even in the classroom, or it was not still contextualized through such social cases.

\section{References}

Abd-El-Khalick, F. (2001). Embedding Nature of Science Instruction in Preservice Elementary Science Courses: Abandoning Scientism, But... Journal of Science Teacher Education, 12(3), 215-233.

Abd-El-Khalick, F.,\&Lederman, N. G. (2000). Improving science teachers' conceptions of the nature of science: A critical review of the literature. International Journal of Science Education, 22(7), 665 -701 .

Aikenhead, G. S., \& Ryan, A. G. (1992). The Development of a New Instrument: 'Views on ScienceTechnology—Society'(VOSTS). Science Education, 76(5), 477-491.

Allchin, D. (2014). From science studies to scientific literacy: A view from the classroom. Science \& Education, 23(9), 1911-193. 
Allchin, D. (2017). Beyond the consensus view: Whole science. Canadian Journal of Science, Mathematics and Technology Education, 17(1), 18-26.

Aslan, O., Yalçin, N., \& Taşar, M. F. (2015). Fen ve Teknoloji Öğretmenlerinin Bilimin Doğası Hakkındaki Görüşleri. Ahi Evran Üniversitesi Kırşehir Eğitim Fakültesi Dergisi, 10(3), 1-8.

Barufaldi, J. P., Bethel, L. J., \& Lamb, W. G. (1977). The Effect of a Science Methods Course on the Philosophical View of Science Among Elementary Education Majors. Journal of Research in Science Teaching, 14(4), 289-294.

Brickhouse, N. W. (1989) The Teaching of the Philosophy of Science in Secondary Classrooms: Case studies of teachers' Personal Theories. International Journal of Science Education, 11 (4), 437 449 .

Carey, R. L., \& Stauss, N. G. (1970). An Analysis of Experienced Science Teachers' Understanding of the Nature of Science. School Science and Mathematics, 70(5), 366-376.

Deng, F., Chen, D. T., Tsai, C. C. \& Chai, C. S. (2011). Students' views of the nature of science: A critical review of research. Science Education, 95(6), 961-999.

Durant, J.R. (1994). What is scientific literacy?, European Review, 2(1), 83-89.

Duschl, R. A and Wright, E. (1989). A Case Study of High School Teachers' Decision Making Models for Planning and Teaching Science. Journal of Research in Science Teaching, 26 (6), 467-501.

Gürses, A., \& Doğan, Ç. (2005). Bilimin Doğası ve Yüksek Öğrenim Öğrencilerinin Bilimin Doğasına Dair Düşünceleri. http://www.metabilgi.org/Metabilgi [Access Date: 12 of November, 2018].

Hashweh, M. Z. (1996). Effects of Science Teachers' Epistemological Beliefs in Teaching. Journal of Research in Science Teaching, 33(1), 47-63.

Hodson, D. (2008). Towards Scientific Literacy. Rotterdam, The Netherlands: Sense.

Irzık, G., \& Nola, R. (2011). A Family Resemblance Approach to the Nature of Science for Science Education. Science \& Education, 20(7-8), 591-607.

Jenkins, E. W., (1996). The 'Nature of Science' as a Curriculum Component. Journal of Curriculum Studies, 28(2), 137-150.

Justi, R., \& Gilbert, J. (2000). History and Philosophy of Science through Models: Some Challenges in the Case of' the Atom'. International Journal of Science Education, 22(9), 993-1009.

Kaya, E., \& Erduran, S. (2016). From FRA to RFN, or How the Family Resemblance Approach can be Transformed for Science Curriculum Analysis on Nature of Science. Science \& Education, 25(910), 1115-1133.

Klopfer, L. E., \& Cooley, W. W. (1961). Test on Understanding science, Form W. Princeton, NJ: Educational Testing Service.

Klopfer, L. E., \& Cooley, W. W. (1963). The History of Science Cases for High Schools in the Development of Student Understanding of Science and Scientists: A report on the HOSG Instruction Project. Journal of Research in Science Teaching, 1(1), 33-47. 
Kolstø, S. D. (2001). Scientific literacy for citizenship: Tools for dealing with the science dimension of controversial socioscientific issues. Science Education, 85(3), 291-310.

Lakatos, I. (1971). History of Science and Its Rational Reconstructions. In PSA 1970 (pp. 91 136). Springer, Dordrecht.

Latour, B. (1987). Science in Action. Cambridge, MA: Harvard University Press.

Lederman, N. G. (1992). Students' and Teachers' Conceptions of the Nature of Science: A Review of the Research. Journal of Research in Science Teaching, 29(4), 331-359.

Lederman, N. G., (2007). "Nature of Science: Past, Present, and Future”, Handbook of Research on Science Education, 2:831-879.

Lederman, N. G., Abd-El-Khalick, F., Bell, R. L., \& Schwartz, R. S. (2002). Views of Nature of Science Questionnaire: Toward Valid and Meaningful Assessment of Learners' Conceptions of Nature of Science. Journal of Research in Science Teaching, 39(6), 497-521.

Lin, H. S., \& Chen, C. C. (2002). Promoting preservice chemistry teachers' understanding about the nature of science through history. Journal of Research in Science Teaching, 39(9), 773-792.

Mackay, L. D. (1971). Development of Understanding about the Nature of Science. Journal of Research in Science Teaching, 8(1), 57-66.

Maggioni, L., \& Parkinson, M. M. (2008). The Role of Teacher Epistemic Cognition, Epistemic Beliefs, and Calibration in Instruction. Educational Psychology Review, 20(4), 445-461.

Masson, S., \& Vázquez-Abad, J. (2006). Integrating History of Science in Science Education through Historical Microworlds to Promote Conceptual Change. Journal of Science Education and Technology, 15(3-4), 257.

Matthews, M. (1998). In defense of modest goals when teaching about the nature of science. Journal of Research in Science Teaching, 35(2), 161 - 174.

McComas, W. F., Clough, M. P., \& Almazroa, H. (1998). The Role and Character of the Nature of Science in Science Education. In The Nature of Science in Science Education (pp. 3-39). Springer, Dordrecht.

Mıhladız, G., \& Doğan, A. (2010). Fen Bilgisi Öğretmen Adaylarının Bilimin Doğası Konusundaki Pedagojik Alan Bilgilerinin Araştırılması. Hacettepe Üniversitesi Eğitim Fakültesi Dergisi 32(2), 380-395.

Millar, R., \& Osborne, J. (1998). Beyond 2000: Science education for the future (the Report of a Seminar Series Funded by the Nuffield Foundation). London: King's College London, School of Education.

Monk, M., \& Osborne, J. (1997). Placing the History and Philosophy of Science on the Curriculum: A Model for the Development of Pedagogy. Science Education, 81(4), 405-424. 
Niaz, M. (1998). From Cathode Rays to Alpha Particles to Quantum of Action: A Rational Reconstruction of Structure of the Atom and its Implications for Chemistry Textbooks. Science Education, 82(5), $527-552$.

Niaz, M. (2001). Understanding Nature of Science as Progressive Transitions in Heuristic Principles. Science Education, 85(6), 684-690.

Niaz, M. (2016). Nature of Science in Science Education: An Integrated View. In Chemistry Education and Contributions from History and Philosophy of Science (pp. 37-89). Springer, Cham.

Niaz, M., \& Coştu, B. (2009). Presentation of Atomic Structure in Turkish General Chemistry Textbooks. Chemistry Education Research and Practice, 10(3), 233-240.

Niaz, M., \& Rivas, M. (2016). Students' Understanding of Research Methodology in the Context of Dynamics of Scientific Progress. Springer.

Osborne, J. (1997). Science education for the future - the road ahead? Paper presented at the First International Conference of the European Science Education Research Association, Rome.

Osborne, J., Collins, S., Ratcliffe, M., Millar, R., \& Duschl, R. (2003). What "Ideas-about-Science" Should be Taught in School Science? A Delphi Study of the Rxpert Community. Journal of Research in Science Teaching, 40(7), 692-720.

Özdemir, O. (2010). Fen ve Teknoloji Öğretmen Adaylarının Fen Okuryazarlığının Durumu. Türk Fen Ĕgitimi Dergisi, 7(3), 42-56.

Özden, M., \& Cavlazoğlu, B. (2015). İlköğretim Fen Dersi Öğretim Programlarında Bilimin Doğası: 2005 ve 2013 Programlarının İncelenmesi. Ĕgitimde Nitel Araştırmalar Dergisi, 3(2), 40-65.

Ryder, J. (2001). Identifying science understanding for functional scientific literacy. Studies in Science Education, 36, 1-44

Savin-Baden, M., \& Major, C. H. (2013). Qualitative research: The essential guide to theory and practice. Routledge.

Scharmann, L. C. (1990). Enhancing an Understanding of the Premises of Evolutionary theory: The Influence of a Diversified Instructional Strategy. School Science and Mathematics, 90(2), 91-100.

Seung, E. S., Bryan, L. A., \& Nam, J. H. (2009). Korean Pre-Service Teachers' Understanding about the Nature of Science (NOS). Journal of the Korean Association for Science Education, 29(3), 314328.

Smith, M. U., \& Scharmann, L. C. (1999). Defining Versus Describing the Nature of Science: A Pragmatic Analysis for Classroom Teachers and Science Educators. Science Education, 83(4), 493-509.

Solomon, J., Duveen, J., Scot, L., \& McCarthy, S. (1992). Teaching about the Nature of Science through History: Action Research in the Classroom. Journal of Research in Science Teaching, 29, 409421.

Tsai, C. C. (2002). Nested Epistemologies: Science Teachers' Beliefs of Teaching, Learning and Science. International Journal of Science Education, 24(8), 771-783. 


\section{Genişletilmiş Özet \\ Fizik ve Kimya Eğitiminde Bilimin Doğasının Öğretimi: Eleştirel Bir Bakış}

Anahtar Kelimeler: Bilimin Doğası, Epistemolojik Görüşler, Fen Eğitimi

Fen bilgisi eğitimi alanında birçok araştırma ve çalışma fen bilgisi eğitiminde bilimin doğasını öğretiminin önemini vurgulamış ve birçoğu da bu amacın fen eğitiminin nihai hedefi olduğunu iddia etmişlerdir. Bu önem, fen eğitiminin tüm bileşenlerini, okul ortamından müfredat içeriğine yansıtacak şekilde vurgulamıştır. Ayrıca, birçok araştırma fen bilgisi öğretmenlerinin bilimin doğası ve epistemolojisi hakkındaki inançlarının öğretim uygulamalarına doğrudan etkisi olduğu görüşünü benimsemektedir. Geçmişte Dünyada ve Türkiye'de, fen öğrencileri ve fen öğretmenleri bilimin doğası ve epistemolojisi hakkında modern felsefi yaklaşımlara uygun bilgi, görüş ve inanışlara sahip olsunlar diye birçok çalışma yapılmıştır. Fakat bu kadar girişime rağmen, araştırmaların çoğu tatmin edici olmayan sonuçlar göstermiştir. Bu bilgiler ışığında bu çalışmanın iki ana amacı vardır. İlk amaç, ikinci sınıf öğretmen adaylarının bilimin doğası hakkında nasıl düşündüklerini ortaya çıarmak ve epistemolojik inançlarını tespit etmektir. İkinci olarak, elde edilen sonuçları Dünya da ve Türkiye'de bu bağlamda yapılan örnek çalışmalar ile karşılaştırarak değerlendirmektir. Bir başka deyişle geçmişte gerek müfredat gerekse öğretimde yapılan gayretler ile bu sonucu değerlendirmektir.

Bilimin doğasının öğretimini fen okuryazarlığının bir parçası olması, ilerde bilim insanı olmak isteyen öğrencilere yol gösterici olması ya da günlük yaşamında yaşadığı tecrübelere bilimsel bir anlayışla yaklaşan bireyler yetiştirilmesinde büyük etkisinin olması üzerinde çoğu fen eğitimcisi mutabık hale gelmiştir. Bu amaçla geçmişte birçok çalışma yapılmış, öğretim yöntemleri geliştirilmiş, bu konu ile ilgili görüş ve bilgilerini ortaya çıkarmak için birçok test geliştirilmiştir. Ne yazık ki yapılan birçok tarama çalışması öğrencilerin, fen bilgisi öğretmen adaylarının hatta fen bilgisi öğretmenlerinin istenilen seviye de olmadıkları ortaya konulmuştur. İstenilen seviye kriteri genel olarak modern bilim felsefesinin ve epistemolojisinin ortaya attığı görüşleri ile örtüşme seviyesidir. Bu görüşler kabaca bilimin insan yapımı olduğunu, bilimsel bilginin geçiciliğini, bilimsel bilginin bilim insanlarının keşfettikleri değil icat ettiği bilgi olduğu, bilimsel model ve teorilerin doğal gerçeğin kopyası değil, doğal olguyu açıklayabilmek için o zaman ortaya attıkları çözüm oldukları düşüncelerini savunur. Bu çalışmanın kapsamında, bu görüşlerin zıttı pozitivist sayılmıştır. 
Bilimin doğasının tanımı ve bağlamsallaştırılması hala tartışmalı konulardır. Kolsto (2001), fen eğitimi bilimcileri arasında ders kitabı bilimi ve bilim sınırı arasındaki gerginliği ortaya koysa da, görüş birliği savunucularının fikir birliği görüşünün tartışmalı olmadığını iddia ettiklerini, çünkü eleştirmenlik, argümantasyondan sonra bilim eğitim topluluğu tarafından belirlendiğini belirtmektedir. ve akran gözden geçirme süreçleri "Bilimsel eğitimcilerin bilimin doğası ile ilgili ortaya koyduğu temel sorunları ve sorunları tartışmak bu çalışmanın kapsamı için çok geniştir ve bu, Allchin'in (2017) tartışmalı hak iddialarına ilişkin makul bir iddiaya yönelik öneriyi vurgulayamaz. Ona göre "bilimin doğası Nedir?" sorusunun cevabını ele almadan önce "Neden bilimin doğasını öğretmeliyiz?" sorusunu kendimize sormalıyız. Fen eğitimi araştırmacılarının bilimin doğasını "yeterli gerekçe olmadan” öğretiminin gerekliliğini kabul ettiğini ekliyor. Öğrencilerin bilimsel iddiaların güvenilirliğini özellikle sosyo-bilimsel konularda yorumlamak için bilimin nasıl çalıştığını anlamaları gereken işlevsel bilimsel okuryazarlık için "neden bilimin doğası" cevabını ortaya koydu. Böyle bir bilimin doğası anlayışı laboratuvarda başlar ve gazetelere devam eder, başka bir deyişle, öğrenciler bilimsel bilginin nasıl üretildiğini, kavramsallaştırıldığını ve sosyalleştiğini bilmeli ve böyle bir farkındalıkta öğrencilerin önyargıları, kültürel, etkileri, hataları veya çıkar çatışmaları konusunda uzmanlık sahibi olmalıdırlar. Modern toplumda vatandaşlar ve tüketiciler olarak. Böyle bir pragmatik ve işlevsel yaklaşımda, Allchin (2014), bilimin doğasının kavramsallaştırılabileceği ve mantıksal olarak bilimin doğası öğretiminin bilişsel, pratik yönlerini ve öğretme yollarını önermektedir. Öğrenci bilimsel uygulama ve sorgulama faaliyetleri, çağdaş yaşantılar ve tarihsel yaklaşım olarak üç kavramsallaştırma yöntemi önermektedir.

Bilimin doğası ile ilgili görüşleri ortaya çıarmak için ilk olarak Aikenhead ve Ryan (1992) tarafından geliştirilen ve Solomon ve diğerleri (1992) tarafından amaca özel hale getirşlen VOSTS testi kullanılmıştır. 45 hizmet öncesi fen bilgisi öğretmenleri bu sorulara cevap vermiş ve sonuçlar nicel olarak analiz edilmiştir. Sonuçlar, on maddenin sekizinde çoğunluğun pozitivist bir yaklaşımla yanıtlandığını göstermiştir. Anket sonuçları, katılımcıların çoğunun pozitivist görüşlere sahip olduklarını gösterdiği için, bilimin doğası ve epistemolojisine yönelik anlaşılma düzeyinin hala tatmin edici olmadığ 1 bulunmuştur. $\mathrm{Bu}$ bulgulardan yola çıkarak neden halen bilimin doğasına yönelik pozitivist anlayış üniversite ikinci sınıfta okuyan fen bilgisi öğretmen adayları arasında baskındır? Bu sorunun olası iki cevabı Lederman (2007) ve Monk ve Osborne (1997)' nin ortaya attığı düşünceler kapsamında ele alınmıştır. 
Lederman (2007) bilimin doğasının öğretimi tek bir parametre açısından sağlanamayacağını bu amaca ulaşılabilmesi için bütünsel olarak yaklaşılması gerektiğini savunmuştur. $\mathrm{Bu}$ parametreler öncelikle öğretmen anlayışını ve öğretim pratiklerini, fen bilgisi müfredatını, okulun öğrenciye sunduğu eğitsel olanak ve çevreyi, ders kitaplarının bu amaca uygunluğunu ve hatta okulun yönetilme şeklini bile içerir. Bu parçalar bir bütündür ve bu bütünde ki herhangi bir eksiklik sonucun da uyumsuzluk oluşur.

Monk ve Osborne (1997) ise bilimin doğasına yönelik geliştirilen anlayış ile insanlık tarihinde gelişen bilimsel anlayış bağlamında bir kronolojik benzeşim ortaya atar. Örneğin 6 yaşında atılan bir taşın nasıl hava da bir süre kalıp sonra yere düştüğü hakkında ki açıklaması Aristo'nun ortaya attığ açıklama ile eşdeğer sayar veya Galileo'nun düşen bir cismin düşüşünü bilimsel bir dille açıklaması 12 yaşında ki bir çocuğun getirdiği anlayış ile örtüştürür. Bu yaklaşıma göre öğrenerek ilerleyen bir öğrenciden üniversite yıllarında modern bir görüşe sahip olarak doğal olguları açılayabilmeleri ve bunları açılamaya çalışan bilimsel felsefi görüşe sahip olmaları beklenir.

$\mathrm{Bu}$ çalışma sonucunda Lederman (2007)'nin savunduğu bilimin doğasının ve epistemolojisinin öğretiminde bütünsel yaklaşımın uygulanamadığı sonucuna varılmıştır. Nitekim fen bilgisi öğretmenliği lisans müfredatında bilimin doğasının ayrı bir ders olarak yürütülmektedir. Fakat ders kitaplarının seçilmesinde bu düşünce dikkate alınmakta mıdır? Örneğin Niaz ve Coştu (2009) yaptığı çalışmada 21 üniversite genel kimya kitabını bilimin doğası açısından incelemiş ve neredeyse hepsini pozitivist bir açıdan yazılmış olarak bulmuştur. Ayrıca bu çalışmaya katılan fen bilgisi öğretmen adayları genel kimya dersinde Niaz ve Coştu (2009)'un analiz ettiği ve pozitivist bir bakışla yazılmış olduğu kanısına vardıkları kitabı kullanmışlardır. $\mathrm{Bu}$ bulgular Lederman (2007)'nin bilimin doğasının öğretiminin bir bütünsel olarak düşünülmesi ve tüm elamanlarıyla tasarlanması gerektiğini desteklemektedir. Fakat bu destek fen eğtimcilerinin yapılandırmacı eğitim bağlamında bilimin doğası öğretiminde baskın görüş olan "consensus view" bağlamında geçerlidir. $\mathrm{Bu}$ görüşe karşı, örneğin, Kolsto (2001), Ryder (2001) ve Allchin (2017) tarafından bilgi okuryazarlılığı çerçevesinde getirdikleri eleştiri ve sınırlılıklar bu görüşe uygun öğretimin optimal seviyede öğretilse bile özellikle sosyo-bilimsel konularda geçerliliğinin çok az olacağı yönündedir. Bir başka deyişle bilimin doğası hakkında istenilen düzeye gelinememesinin görünen en büyük nedeni bu bilişsel seviyede kalması ve günlük yaşamda karşılaştıkları durumlarla içselleştirememeleridir. 